Yevhen Mishenin,

D.Sc., Professor, Sumy State University, Ukraine;

Inessa Yarova,

Ph.D., Associate Professor, Sumy State University, Ukraine;

Halyna Mishenina,

Ph.D., Associate Professor, Sumy State University, Ukraine.

\title{
FEATURES OF FORESIGHT METHODOLOGY APPLICATION IN THE FORESTRY COMPLEX OF UKRAINE: SECTORAL AND SPATIAL ASPECT
}

\begin{abstract}
This article substantiates the content basis of application of the foresight methodology in the forestry complex in the context of sustainable spatial forestry management. The socio-ecological and economic effectiveness of sustainable forestry is determined by the completeness of continuous and non-exhaustive use of all components of forest ecosystems, including non-market, at all levels of spatial development (local, regional, national and global). It stipulates the high responsibility of the world community, society, state, local authorities and businesses for political, institutional, economic, technological, and project decisions in the sphere of forestry management in the spatialtemporal dimension. It leads to the need for qualitative forecasting of the future sustainable development of the forestry complex, which determines the search and application of modern effective approaches to strategic planning and management of the forestry complex, among which foresight is particularly highlighted. Thus, the paper considers the key features of foresight, which must be taken into account when investigating the future vision of sustainable spatial development of forestry. Thus, the purpose of this study is to generalize and identify the features and possibilities of using the foresight methodology in the forestry complex in the context of sustainable spatial development. The particular features of nature management in the forestry complex in the process of foresight research should be taken into consideration. Existing principles and classification signs for the foresight are presented in the context of sustainable forestry. The application of existing foresight methods is implemented on the example of using the scenario approach to the substantiation of organizational and economic conditions for the formation and development of ecosystem entrepreneurship. At the same time, we have considered the application of the scenario approach within the framework of solving the problem of forest ecosystem business development. The development of entrepreneurship on the ecological and economic basis should become a qualitatively new and effective type of forestry management based on the use of advanced, innovative methods, forms, methods of production organization and combination of resources. The variable development of the use of the scenario approach to the substantiation of organizational and economic conditions for the formation and development of forest ecosystem entrepreneurship has been presented. Thus, the use of various foresight technologies (in particular, the scenario approach) will provide a qualitatively new level of constructive substantiation, in particular, the national strategy for sustainable forestry and long-term forestry programs on an innovative basis.
\end{abstract}

Keywords: foresight, forestry complex, sustainable spatial forestry, foresight principles, foresight classification, scenario, ecosystem entrepreneurship.

Introduction. The long-term process of the forest growing, the national and global multi-purpose value of economic, ecological and social functions of forest resources determines their strategic importance. The socio-ecological and economic effectiveness of sustainable forestry is determined by the completeness of continuous and non-exhaustive use of all components of forest ecosystems, including non-market, at all levels of spatial development (local, regional, national and global). It stipulates the high responsibility of the world community, society, state, local authorities and businesses for political, institutional, economic, technological, and project decisions in the sphere of forestry management in the spatial-temporal dimension.

Cite as: Mishenin, Y., Yarova, I. \& Mishenina, H. (2019). Features of Foresight Methodology Application in the Forestry Complex of Ukraine: Sectoral and Spatial Aspect. Marketing and Management of Innovations, 4, 229-240. http://doi.org/10.21272/mmi.2019.4-18 
This paper aims to explain the necessity of qualitative forecasting of the future sustainable development of the forestry complex, which implies the search and application of modern effective approaches to strategic planning and management of the forestry complex (such as foresight).

It should be noted that the interest and need for the future of sustainable forest management and the formation of strategies for achieving the goals set at various levels of spatial development are due to the fact that the foresight methodology, according to (Gohberg, 2007) is:

- system of methods of expert assessment of long-term prospects for innovation development, the discovery of technological breakthroughs, capable of affecting the economy and society in the most favourable way;

- analysis of phenomena that involve control and management;

- expression of tactical and strategic competitive advantages, planning and the organization of systematic actions to achieve tangible effects for the economy and society;

- a combination of «product» (forecasts, scenarios, priorities) and "process» (establishing links between all stakeholders) that promotes not only the prediction of the future but also the achievement of consensus in society, based on a systematic dialogue between politicians, professionals and businessmen;

- complex phased and multidimensional interaction of expert groups representing different spheres of activity.

Therefore, such a complex character of foresight research, in comparison with traditional methods of socio-economic forecasting, today gradually provides the formation of an innovation-oriented view on the future of forestry (Pisarenko et al., 2008).

Literature Review. First of all, it should be noted that since the beginning of the 21 st century, foresight has been actively used as a new effective tool for strategic planning and management in the context of strategic forestry's future (Kirnos, 2013). The main recognized foreign authorities in shaping the general foresight methodology should be noted by such scholars as T. Cuosa (Cuosa, 2011), R. Popper (Popper,2008), B. Habegger (Habegger,2010), E. Hideg (Hideg, 2007). There is a certain beginning of the use of foresight methodology in Ukraine, especially in the sectoral aspect, and most studies focus on socio-economic trends and contradictions (Rudakevych et al., 2015). For example, the latest publications include research concerning the foresight of national welfare (Gluschenko, 2018). Of course, the scope of the use of the foresight methodology is diverse and covers, for instance, regional development (Tsedik, 2016), the agricultural sector (Kravchenko, 2015), ecological and economic issues (Obykhod, 2016; Hubanova et al., 2016).

Scientific publications regarding the development of foresight technologies in the forestry complex are represented mainly by foreign researchers: Strakhov (2008), Pisarenko et al. (2008).

As a matter of fact, foresight in the forestry sector of Ukraine does not find the necessary development. In (Karpuk, 2012), for example, the results of the application of the foresight method in the forestry sector are mainly presented in the developed countries. Despite this, it is noted that the success of forestry reform in Ukraine depends on how frankly and widely the national forestry strategy will be discussed to a large extent by scientists and practices. Therefore, mastering foresight technologies will allow a discussion on the qualitatively new level, more clearly define the strategic objectives of the forestry sector from afforestation towards wood processing in the spatial dimension. From these perspectives, for example, uneven distributive of forest lands, forests and forest resources, the inter-sectoral economic value of forest raw materials, low predictability of scientific and technological progress in such areas as logging, reforestation, forest resources protection and conservation, export and wood processing, inventory and design technology can be the subject of strategic estimation (Strahov, 2008).

Highlighting previously unresolved parts of a common problem. It is worth noting that there is an insufficient systematization of the main foundations regarding the peculiarities of the use of foresight 

Sectoral and Spatial Aspect

methodology in the forest complex in the format of sustainable spatial forest management in conditions of increasing the environment-transforming value of forests.

The purpose of the article is generalization and definition of peculiarities and possibilities of using the foresight methodology in the forestry complex in the context of the sustainable spatial development of the forestry management.

Methodology and research methods. The methodological basis is the methodology of a systematic approach to the study of the spatial organization of natural and economic structures. The research is based on the modern paradigm of the sustainable spatial development of forestry, which is based on the principles of integrated and multi-purpose use of forest resources in the territorial-spatial dimension that determines the features of the use of foresight technologies in the forest complex.

The use of system-structural, abstract-logical and comparison methods made it possible to summarize and deepen the main content and substantive foundations concerning the features of applying foresight methodology in the forest complex from the perspectives of sustainable spatial forestry.

Results. Modern strategic directions concerning the post-industrial sustainable development of the forestry complex cause the formation of a new methodology for the forestry research when the territory is considered not only as a physical (natural and geographic) basis for the forestry management but as a space for the development of forestry relationships and socio-environmental and economic interests, also information, innovation and knowledge processes in a competitive environment. It requires, as we have noted, the use of effective tools for determining the strategic prospects of the sustainable spatial development of the forestry complex based on the foresight methodology, which is actively used in developed countries at all hierarchical levels of spatial management (local (in particular, corporative), regional and national). It is important to indicate that there is a certain versatility of definitions for the concept of foresight, and therefore in scientific publications, they are subjects for the analysis (Rudakevych et al., 2015; Kravchenko, 2015; Kvitka, 2016; Mushchynska, 2015).

Therefore, in the framework of the analysis of the substantive content of the «foresight» definitions, the researchers identify the following key features that are necessary and should be taken into account when investigating the future vision of sustainable spatial forestry development:

1. The common feature in existing interpretations of foresight is that this notion is seen as a process with the aim to determine the possible future of creating its desirable image, as well as to define the strategies for achieving it (Kvitka, 2016). The most cited is the definition of the concept of foresight by the authorship of Ben Martin: «Foresight is the process involved systematically attempting to look into the long-term future of science, technology, the economy and society with the aim of identifying the areas of strategic research and the emerging technologies likely to yield the greatest economic and social benefits» (Martin,2002).

Thus, the main directions of development of the European Forestry Sector by 2030, as a result of foresight, include the following strategic tasks (Strahov, 2008):

- production of innovations for a changing market and consumer inquiries;

- creation of intelligent, energy-saving production;

- increasing the quality of forest biomass and its use in the production of forest products and energy;

- combination of multilateral demand for the forest resources in the context of sustainable management;

- the forestry sector from the social perspective.

2. The main difference between foresight and forecasting is a procedural, a broad format for the participation of stakeholders (politicians, professionals, businessmen), greater openness and an ability of the participants to influence the future perspectives, which may come under the certain circumstances: the correct definition of scenarios for development, the achievement of consensus concerning the choice of the desired and favourable scenario with appropriate measures for its implementation (Kirnos, 2013). 
Therefore, foresight improves strategic forestry management through both specific products (in particular, in the format of forestry management and forestry projects), as well as the participation of stakeholders in the foresight process.

3. Foresight universally integrates instruments of scientific and technological and socio-economic policy, which allow determining the breakthrough trends («arrows») of modernization by types of economic activity, which ensure the growth of competitiveness of the economy and maximize the effect of the use of accumulated potential (Klimova,2012). And here must be emphasized the need for the forestry policy formation based on the use of the foresight methodology, since it has primarily defined the strategic objectives of the forestry, along with the tactical, as well as the basic principles of sustainable forestry development at different spatial levels (local, regional, national and global), which are closely connected with the rational use of forest resource potential (Yarova et al., 2018). In this case, the spatial content of forestry management should take into account the objectives of sustainable forestry. The key criteria of sustainability for Ukrainian forestry such as preserving biological diversity, productive capacity, productivity, the vitality of forest ecosystems and human dimensions are substantiated by their environmental, social and economic functions (Petrov, 2004).

Thus, the purpose of the national forest programs concerning the foresight is to describe trends in socio-ecological and economic and innovation-technological development of sustainable spatial forestry management for the long-term perspective and achieve consensus between the state, business and society in the system of forest-resource relationships for strategic areas of forestry.

4. The fundamental principle of foresight is that perception of the future governs the current events and trends. Therefore, the present corresponds to the conceptual space of the future, which focuses on the non-existing context, prompts to go beyond the limits of fleeting interests and, in the end, contributes to the formation of a broader view of the prospects of development. Thus, the emerging vision of the future will stimulate the development of strategies and preventive action plans (Rudakevych et al., 2015). This concerns the future development of diverse markets for the forest ecosystem services (Mishenin et al., 2011; Suska, 2018), as well as globalization of the forestry (Mishenin, 1998, p.228-229). The system of strategic planning (forecasting) of sustainable spatial forestry in the conditions of globalization of forestry, is much more complicated and should become more qualitative.

Foresight research within the framework of sustainable spatial forestry's strategic processing should take into account the following basic principles of forest globalization:

- civilized conservation of forests, increase of the area of forest-cultivated production and artificial forests of certain countries and the planet as a whole for a more complete (integrated) meeting the needs of mankind in forest resources, in their various socio-ecological and economic functions, material goods and ecosystem services;

- development of a system of criteria and indicators of sustainable and ecosystem management of global forestry in the territorial and spatial dimension regarding the balanced mix of national and planetary interests;

- the non-conflict solution of the problem of wood resources' world trade, which is associated with forestry's industry at different spatial levels of the forestry management;

- creation of innovative, more balanced, financial and economic mechanisms for ensuring the sustainable forestry at hierarchical levels of sustainable spatial management;

- development of favourable organizational and institutional conditions for provision of interstate, intergovernmental and inter-organizational relations on the various spatial levels of the forestry in order to ensure the management of sustainable forest resource development at various spatial levels (regional, national and global);

- expansion of participation in strategic planning and forecasting of sustainable forestry development of different social classes; 
- environmentally balanced development of inter-sectoral integration in the national forestry complex and the international economy.

5. It is worth noting that in recent years foresight is defined not only as a method of predicting the future but also as a special technology, representing the unity of the three components - foresight, strategic management and political decisions (Malinovskaya et al., 2014). There is a concept of «complete foresight», which includes three key features, namely, the impact of project results on political decisions, participativeness, as well as its orientation towards the study of the future (Miles, 2004).

Thus, we outline the main key points that reflect the substantive content of the concept of «foresight» with an emphasis on their possible manifestations in the spatial forestry. Taking into account the existing practice of strategic planning in the forestry sector of developed countries and taking into consideration the diverse nature of reproductive processes in forestry (from afforestation to wood processing), spatial and temporal features of forestry, development of strategies for the sustainable forestry should be based on the use of the methodology of foresight.

Foresight, in our opinion, is a systematic process of collective formation of an understanding of peculiarities and characteristics of the future forestry in the midpoint and long - term perspective. The main objective is to maximize the consideration of these peculiarities and characteristics today in shaping strategic management decisions, as well as in regulating and stimulating actions for achieving the necessary realities of the future state of forestry and forest - resource potential (capital) (Yarova, 2018).

In other words, based on foresight, support of strategic management decisions is carried out through the development of alternative scenarios of spatial-temporal forestry development, in which each option for future sustainable forestry depends on decisions made today. From these perspectives it is important to dwell on the sectoral features of forestry, which are largely in geographically spatial and temporal dimensions:

1. The main sectoral feature that defines the specifics of the forestry economy is unprecedented (in comparison with other industries) long-term nature of reproduction of forests as the main means of production and management. This requires time comparing the amount of material (food) use of forest and resource potential with the scale and pace of its reproduction in the spatial dimension. Such a requirement is known to be based on the principle of continuous and non-exhaustive use of forests (Moiseev, 2010), which largely determines the sustainable forestry management.

The basic complexity of the formation of market-oriented motivators for the forestry management and the use of economic indicators in assessing the results of the use and reproduction of forest biogeocoenoses in the spatial and temporal dimension is the duration of reproductive processes, which leads to a lack of matching of costs and effects.

Thus, the application of foresight technologies in forestry will always face this problem. However, time barriers and impediments can be eliminated if the territorial and spatial (regional) set of forest ecosystems with a certain level of economic, ecological and social functions (services) is taken into account in the context of strategic planning (designing, programming), not separate forest lands (Mishenin,1998,p.136).

As the classic of forestry shows, the time factor has its manifestation in the fact that the mistakes which have been made in forestry at the beginning of reproductive forestry processes cannot be corrected later in the future. This feature particularly emphasizes the need for variable forecasting of the transformation of forestry space in the process of foresight-designing of forestry.

2. Subordinated to the first feature of the forest as an object of management and strategic planning is its multipurpose nature of resource and ecosystem potential. At the same time, all material (food) resources, ecosystem and social services of the forest, as objects of spatial management and foresight research, are organically linked and cannot be considered separately from each other. The use of each of them should be done considering other resources and services in the general system of strategic objectives set for the forestry, taking into account their subordination, but without opposing each other for 
each category of forests (Moiseev, 2010). Such a characteristic of this sectoral feature defines the relevant requirements for the organization of production and strategic planning of reproductive processes in forestry, as well as strategic management of forestry. The foresight methodology within the forestry management area should take into consideration the fact that multipurpose forestry should provide for the optimal combination of the production of several products and services.

3. Organic combination of natural processes of forest biogeocenoses development with guiding processes of application of labour in the form of the economic system of influence taking into account their purposes, ecological-economic and territorial-spatial (in particular, zonal and typological) conditions. Therefore, it is important to emphasize that the use of the foresight methodology should be based on the platform of a comprehensive socio-ecological and economic assessment of economic impacts on forest ecosystems as an object of management and spatial system. At the same time, it is not necessary to take into consideration separate forestry measures, but their integral (balanced) system for rational use, reproduction, preservation and protection of forest resources. A holistic system of measures in forestry is associated with the specific natural and geographical conditions of forest growth, and therefore it can only be territorial and spatial (regional).

Further, the spatial organization of forestry has other specific features that must also be included in foresight projects (Antonenko,2008,p.25): seasonal forest exploitation, which determines the low employment rate of the population; ineffective spatial organization of forest structures, ineffective allocation that leads to increased transport costs and maintenance of infrastructure that is in surplus within the territories; the regional disproportionality in the development of production structures in the forestry, which is connected with the diversity and inequality of the categories of forest protection; the imbalance of the natural-age structure of forests and their low quality and productivity. All these features should be taken into account in foresight projects concerning sustainable forestry.

It is further important to note the main principles of the foresight toolbox with an emphasis on the socioecological and economic issues of forestry space (Tretyak, 2015, p.54-55):

1. The commitment of various business and entrepreneurial structures, the scientific community, state and local authorities in discussing and comparing long-term forecasts, strategies for sustainable spatial forestry, developing a more comprehensive vision of the forestry future, achieving consensus in the future perspectives.

2. 2.Multi-stakeholder partnership.

3. Long-term concentration, which directly corresponds to the sectoral features of forestry.

4. Coordination, which means that science and technologies in the system of spatial forestry are evaluated in connection with socio-ecological and economic achievements in relation to sustainable forestry.

5. Consent - the necessity of coordinated work of business and entrepreneurial structures, the scientific community, state authorities and forestry management, as well as civil society on the basis of expert-developed scenarios.

The classification of species of foresight focusing on the sectoral features of spatial forestry has been formed on the basis (Malinovskaya et al., 2014; Tretyak, 2015, p.53-86).

1. By the way of (type) formation of foresight projects (from the top and bottom).

1.1. Foresight top-down - the initiative to create foresight projects is coming from the top, and the interaction in this system is paid insignificant attention.

1.2. Foresight bottom-up - the initiative for creating foresight projects is coming from the bottom and is based on the active interaction between science and civil society.

2. By the subject of foresight.

2.1. Thematic foresight covers the whole forestry or separate forestry sectors, as well as various spheres of implementation of ecological, social and economic functions of forests. 

Sectoral and Spatial Aspect

2.1. Corporate foresight projects are aimed at substantiation of forest-ecological, technological priorities; identification of the main factors influencing changes in the forestry markets; assessment of potential multi-purpose forestry products that may be in demand for market-oriented forestry (in particular, it concerns ecosystem forest services); consideration of organizational and technological potential of forest clusters; substantiation of innovative mechanisms of organizational and economic provision of integrated multipurpose forestry use.

2.1. Territorial (territorial-spatial) foresight - represents a vision of the future development of territorial forestry (forest-resource) complexes within certain natural-geographical zones, which can be differentiated by the envelope of forest-based territorial-spatial education into interregional, national and regional.

3. By the direction of foresight (with the definition of various combinations).

3.1. Technological.

3.2. Social.

3.3. Environmental.

3.4. Economic.

4. By spheres of using foresight.

4.1. Development of productive forces (technological foresight).

4.2. Development of forest resource potential (forestry and ecological foresight).

4.3. Development of science and innovations (scientific foresight, innovative foresight).

4.4. Development of organizational and economic management mechanisms (foresight management mechanisms).

4.5. Development of human capital in the system of forest relations (socio-economic foresight).

Foresight is an interdisciplinary tool, characterized by the complexity of the use of scientific research methods, which ensures the achievement of reasonable results for the prediction of the future. When conducting a foresight, Delphi's method is most often used (two-stage expert interviews), SWOT-analysis, brainstorming, expert panels, road maps and scenario planning (Rudakevych et al., 2015; Sokolov, 2007).

Construction of scenarios is considered as an important method of studying the future. In relation to forestry, the scenario should also become an analysis tool for the purpose of developing a new forestry policy that describes a possible set of future conditions for sustainable forestry, determining factors, necessary measures, and balanced forest management trends in the spatial and temporal dimension. It should be noted that the scenario approach is used in two ways: first, to give as a snapshot of the object of research in time or to describe the state of important variables in a certain time in the future; and secondly, to describe the course of events, that is, their evolution from the present state to one of the possible states in the future. This approach is more acceptable because it allows us to construct a causal chain of conditions, events, factors and solutions that arise in the present. The most effective scenarios are those that demonstrate the dynamics of the indicators characteristic of the development of the system. With this approach, quantitative assessments enrich qualitative scenarios. The purpose of developing scenarios is to explore a variety of strategic decisions that can bring maximum benefits, in spite of the existence of various uncertainties and challenges posed by the external environment (Vasylkonova, 2014; Haponenko, 2012).

We use the scenario approach in the context of the problem of forest ecosystem entrepreneurship development. The development of entrepreneurship on the environmental and economic basis should become a qualitatively new and effective type of forestry management based on the application of progressive and innovative methods, forms, methods of production organization and combination of resources (Mishenin et al., 2011). For example, the strategy for the development of forest ecosystem entrepreneurship should be directed on: protection of water basins, watersheds (hydrological regulation); agroforestry; conservation of biodiversity and carbon sequestration by forest ecosystems within the 

Sectoral and Spatial Aspect

framework of regulating climate change (The state, 2009, p.92-95). In this context, it is advisable to emphasize the importance of forest ecosystem services relative to the value of timber (Table 1).

Table 1. Approximate coefficients of ecosystem services assessment of forestries in the annual dimension concerning the value of wood stocks

\begin{tabular}{|c|c|c|}
\hline \multirow{2}{*}{ Type of ecosystem services } & \multicolumn{2}{|c|}{ Natural-geographical area } \\
\cline { 2 - 3 } & Polissja & Lisostep \\
\hline Anti-erosion and field protecting & $\geq 0,648$ & $\geq 0,944$ \\
\hline Water protecting and regulating & 0,155 & 0,098 \\
\hline Sanitary and hygienic & \multicolumn{2}{|c|}{0,120} \\
\hline Recreational & \multicolumn{2}{|c|}{0,060} \\
\hline
\end{tabular}

Sources: own editing based on (Mishenin et al., 2009; Khvesik et al., 2016).

Scenario content of organizational and economic basis for creating conditions for the formation and development of forest ecosystem entrepreneurship involves identification of the necessary institutional and market conditions, ways of their creation, and also the determination of mechanisms and tools (Fig.1). Thus, institutional and market conditions include strengthening of environmental and social standards in forestry policy, market-oriented transformation of forest management and management systems, availability and possibility of realization of property rights in the system of forest-land relations, the formation of a compensatory market-oriented mechanism for the use of ecosystem products and forest services, the balance between supply and demand for forest ecosystem products and services.

Thus, the presented scenario is based on the principle of «top-down» and is based on an analysis of future opportunities for the development of forest ecosystem entrepreneurship (FEE).

The main idea of the foresight methodology for spatial forestry is not traditional strategic planning and forecasting but controlling the desirable future of forestry on an innovative basis using scenario planning methods, the implementation of economic and organizational technologies and mechanisms of a proactive response to the problem, socio-environmental and economic situation. The effectiveness of forestry foresight can be determined, for example, by developing road maps with a detailed description of the strategy and tactics of increasing the effectiveness of sustainable forestry, avoiding conflict situations in the system of spatial forestry. In the system of spatial forestry, foresight - forecasts should include, first, the issue of sustainable forest management and strategic management, as well as the transformation of organizational and economic relations regarding the capitalization of forest resource potential and the financing of integrated multi-purpose forestry (Financial,2016). 
Y. Mishenin, I. Yarova, H. Mishenina. Features of Foresight Methodology Application in the Forestry Complex of Ukraine: Sectoral and Spatial Aspect

\begin{tabular}{|c|c|c|c|c|c|c|}
\hline \multicolumn{7}{|c|}{ Institutional and market conditions for the formation and development of FEE } \\
\hline \multicolumn{2}{|c|}{$\begin{array}{l}\text { Transformation of the forestry policy, } \\
\text { the system of organization and spatial } \\
\text { forestry management on the basis of } \\
\text { sustainable development }\end{array}$} & \multicolumn{2}{|c|}{$\begin{array}{l}\text { Availability and possibility } \\
\text { of realization of property } \\
\text { rights in the system of } \\
\text { forest-resource relations }\end{array}$} & \multicolumn{2}{|c|}{$\begin{array}{c}\text { The ecological and } \\
\text { economic system of } \\
\text { equivalent exchange in } \\
\text { the forestry }\end{array}$} & \begin{tabular}{|c|c|} 
The balance between \\
supply and demand for \\
forest ecosystem products \\
and services
\end{tabular} \\
\hline$\sqrt{5}$ & & $\sqrt{1}$ & & $\sqrt{2}$ & & $\sqrt{1}$ \\
\hline \multicolumn{7}{|c|}{ Ways to create conditions for the formation and development of FEE } \\
\hline $\begin{array}{c}\text { Recognition of forestry activities } \\
\text { by entrepreneurial activity and } \\
\text { formation of economic relations } \\
\text { in the implementation of } \\
\text { ecosystem products and } \\
\text { services } \\
\end{array}$ & \multicolumn{2}{|c|}{$\begin{array}{l}\text { Transformation of forms and } \\
\text { relations of ownership in the } \\
\text { forestry, denationalization } \\
\text { and privatization of forest } \\
\text { lands }\end{array}$} & \multicolumn{3}{|c|}{\begin{tabular}{c|c} 
Identification of forest \\
ecosystem products and \\
services, assessment of their \\
consumer value and \\
availability
\end{tabular}} & $\begin{array}{c}\text { Regulation and motivation of } \\
\text { production and consumption of } \\
\text { forest ecosystem products and } \\
\text { services }\end{array}$ \\
\hline$\sqrt{2}$ & & $\sqrt{2}$ & & $\sqrt{2}$ & & $\sqrt{2}$ \\
\hline \multicolumn{7}{|c|}{ Mechanisms and tools for the formation and development of FEE } \\
\hline \multirow{4}{*}{$\begin{array}{l}\text { Formation of a system of } \\
\text { economic evaluation in the } \\
\text { system of forest resource } \\
\text { relations and realization of } \\
\text { forest ecosystem products } \\
\text { and services }\end{array}$} & \multirow{4}{*}{\multicolumn{2}{|c|}{$\begin{array}{c}\text { Application of various } \\
\text { types of organizational } \\
\text { and legal forms of forest } \\
\text { ecosystem } \\
\text { entrepreneurship }\end{array}$}} & \multirow{4}{*}{\multicolumn{2}{|c|}{$\begin{array}{l}\text { Pricing mechanisms for } \\
\text { forestry and ecosystem } \\
\text { products and services }\end{array}$}} & $\begin{array}{r}\text { Econon } \\
\text { ec }\end{array}$ & $\begin{array}{l}\text { omic mechanisms (forest resource and } \\
\text { ecosystem payments, preferential } \\
\text { taxation, etc.) }\end{array}$ \\
\hline & & & & & & $\begin{array}{l}\text { cological regulation (ecological } \\
\text { works, ecological infrastructure, } \\
\text { agroforestry, etc.) }\end{array}$ \\
\hline & & & & & & $\begin{array}{l}\text { lancial-economic mechanism of } \\
\text { lanagement of territorial forest } \\
\text { complexes on the basis of } \\
\text { apitalization of forest resources }\end{array}$ \\
\hline & & & & & & $\begin{array}{l}\text { Social and environmental } \\
\text { responsibility }\end{array}$ \\
\hline
\end{tabular}

Conclusions. The achievement of an effective transformation of spatial forestry, modernization of the forest complex on the principles of sustainable development and global forestry requires the use of foresight methodology. The need for a strategic vision of the future of forestry management in the spatial and temporal dimension is due to the sectoral features of forestry: first of all, unprecedented long-term forest reproduction processes; project approach to strategic planning based on the forestry management; multi-purpose ecosystem and social value of forest resources; regionalization of the forestry management. The development of the foresight methodology in the forest complex has determined the need to adapt the existing general principles and classifications of foresight to the characteristics of sustainable forestry and strategic forestry management.

The application of various foresight technologies (scenario approach) will provide a qualitatively new level of constructive and multi-dimensional substantiation, in particular, the national strategy for sustainable forestry, and long-term forestry programs on an innovative and ecosystem basis.

Predicting the future will more and more allow the implementation of sustainable spatial forestry management at different hierarchical levels of management (local, regional, national and global) in accordance with the innovative model of forestry development, systematic ecologization of use, reproduction and protection of forest resource potential. 
Further research needs to be focused on determining the procedures for activating the implementation of the foresight methodology on the following key directions of the spatial forestry: the formation of territorial forest and resource capital; formation of environmentally and socially sensitive forest markets; commercialization of forest ecosystem services; perspective implementation of ecologically balanced innovative technologies in forestry-cultivation and integrated multipurpose forestry management and also the processes of use of energy resources of forest ecosystems.

Funding. This research was funded by the grant from the Ministry of Education and Science of Ukraine № 0119 U101860.

Author Contributions: conceptualization of the content basis of foresight in the forestry in the context of spatial development, Y. M. and I. Y.; methodology of sectoral peculiarities of foresight in the sustainable forestry, Y. M.; supervision, Y. M.; investigation, Y. M., I. Y and H. M.; literature reviewing and visualization of the scenario approach to the substantiation of organizational and economic conditions for the formation and development of forest ecosystem entrepreneurship, H. M. and I. Y.

\section{References} Russian).

Gohberg, L. (2007). Buduschee kak strategicheskaya zadacha (The future as a strategic task). Forsayt - Foresight, 1, 4-5 (in

Pisarenko, A.l., Strahov, V.V. (2008). Tehnologiya predvideniya i buduschee lesnogo hozyaystva (Tehnologiya predvideniya i buduschee lesnogo hozyaystva). Lesnoe hozyaystvo - Forestry, 6, 2-6 (in Russian).

Kirnos, I.O. (2013). Forsait yak instrument stratehichnoho planuvannia. (Foresight as a strategic planning instrument). Innovatsiina ekonomika - Innovative economy, 6, 2-6 (in Ukrainian).

Cuosa, T. (2011). Practicing strategic foresight in government. The cases of Finland, Singapore and European Union / Tuomo Cuosa. Singapore: S. Rajaratnam Studies, $116 \mathrm{p}$.

Popper, R. (2008). How are foresight methods selected? Foresight. Vol. 10, 54-59.

Habegger, B. (2010). Strategic foresight in public policy: reviewing the experiences of the UK, Singaporeand the Netherlands. Futures, 42, 49-58.

Hideg, E. (2007). Theory and practice in the field of foresight. Foresight, (6), 36-46.

Rudakevych, O., Biskun, V (2015). Osoblyvosti vykorystannia forsaitu v peredbachenni ta rozviazanni problem u sotsialnii sferi (Features of using foresight in predicting and solving problems in the social sphere). Sotsiolohichni studii - Sociological studios, 2, 77-83 (in Ukrainian).

Gluschenko, O.V. (2018). Primenenie akseleratora ustoychivogo razvitiya v forsayte natsionalnogo blagosostoyaniya Ukrainy (Application of the accelerator of sustainable development in the foresight of the national well-being of Ukraine). Marketing and Management of Innovations, 1, 391-405 (in Russian).

Tsedik, M.H. (2016). Pozvytok rehionalnoho forsaitu yak zasobu terytorialnoho upravlinnia (Development of regional foresight as a means of territorial administration): diss. ... cand.public.admin.: 25.00.02 / Mariia Herasymivna Tsedik. Kyiv, 205 p (in Ukrainian).

Kravchenko, T.A. (2015). Dotsilnist vykorystannia metodolohii forsaitu pry rozrobtsi yedynoi kompleksnoi stratehii rozvytku silskoho hospodarstva ta silskykh terytorii na 2015-2020 rr. (The expediency of using the foresight methodology in the development of the Integrated Integrated Strategy for the Development of Agriculture and Rural Territories for 2015-2020). Aspekty publichnoho upravlinnia - Aspects of public administration, 4(18),121 (in Ukrainian).

Obykhod, H.O. (2016). Prohnozuvannia stanu navkolyshnoho pryrodnoho seredovyshcha iz zastosuvanniam forsaitmetodolohii (Forecasting the state of the environment using foresight methodology). Ekolohichna modernizatsiia v systemi pryrodnotekhnohennoi ta ekolohichnoi bezpeky (Ecological modernization in the system of natural and man-made and ecological safety): monograph / Ed. by prof. M.A. Khvesyk. Kyiv, 345-352 (in Ukrainian).

Hubanova, O.R., Demianenko, S.H. (2016). Forsait yak instrument zabezpechennia sotsialno-ekolohichnoi vidpovidalnosti (Foresight as a tool for ensuring social and environmental responsibility). Stalyi rozvytok - KhKhl stolittia: upravlinnia, tekhnolohii, modeli. Dyskusii 2016 (Sustainable development - XXI century: management, technology, models. Discussions, 2016): monograph I Ed. by Doctor of Economic Sciences, Prof. Ye.V. Khlobystov. Cherkasy:Chabanenko Yu., Part 1.1. (1.7.), 91-102 (in Ukrainian).

Strahov, V.V. (2008). Forsayt v lesnom sektore stran Evropeyskogo Soyuza (Foresight in the forestry sector of the European Union). Forsayt - Foresight, 3(7), 10-15 (in Russian).

Karpuk, A.I. (2012). Zarubizhnyi dosvid vykorystannia forsait-tekhnolohii u lisovomu hospodarstvi (Foreign experience of using foresight technologies in forestry). Naukovyi visnyk NLTU Ukrainy - Scientific Bulletin of the National Forestry University of Ukraine, 22.2, 7-42 (in Ukrainian). 
Y. Mishenin, I. Yarova, H. Mishenina. Features of Foresight Methodology Application in the Forestry Complex of Ukraine: Sectoral and Spatial Aspect

Kvitka, S.A. (2016). Forsait yak tekhnolohiia proektuvannia maibutnoho: novitni mekhanizmy vzaiemodii publichnoi vlady, biznesu ta hromadianskoho pidkhodu (Foresight as a technology for future design: the latest mechanisms of interaction between public authority, businesses and civic approach). Aspekty publichnoho upravlinnia - Aspects of public administration, 8 (34), 5-15 (in Ukrainian).

Mushchynska, N.lu. (2015). Vprovadzhennia forsaitu v upravlinniia sotsialno-ekonomichnym rozvytkom rehionu (Implementation of foresight in the management of the socio-economic development of the region). Visnyk skhidnoukrainskoho natsionalnoho universytetu im. Volodymyra Dalia - Bulletin of the East-Ukrainian National University after V. Dahl, 6. (223), 98-102.

Martin,Ben R. (2002). Technology foresight in a rapidly globalizing. - International Practice in Technology Foresight. Vienna: UNIDO,14 p.

Klimova, N.V. (2012). Integratsiya tehnologii forsayta i tsiklichnosti razvitiya ekonomiki (Integration of foresight technology and cyclical economic development). Byuleten Mizhnarodnogo Nobelivskogo ekonomlchnogo forumu - Bulletin of the International Nobel Economic Forum, 1(15), 1,209-213 (in Russian).

Yarova,I.Ye., Mishenina, N.V., Pizniak, T.I. (2018). Prostorovyi analiz vidtvorennia lisoresursnoho potentsialu: ekolohoekonomichnyi aspekt. (Spatial analysis of the reproduction of forest resource potential: the ecological and economic aspect). Marketing and Management of Innovations, 1,406-418 (in Ukrainian).

Petrov, V.N. (2004). Osnovyi politiki gosudarstva v oblasti lesnyih otnosheniy (Basics of state policy in the forestry). Lesnoe hozyaystvo-Forestry, 4, 2-4 (in Ukrainian).

Mishenin, Ye.V., Mishenina, N.V., Yarova, I.Ye. (2011). Rozvytok marketynhu ekosystemnoi produktsii ta posluh u lisoresursnii sferi (Development of marketing of ecosystem products and services in the forest resource sector). Marketing and Management of Innovations, 2,209-219 (in Ukrainian).

Suska, A.A. (2018). Instytualizatsiia lisovoho sektora ekonomiky Ukrainy u konteksti rynku sotsialno-ekolohichnykh posluh (Institutionalization of the forestry sector of Ukraine's economy in the context of the market of social and environmental services): abstract. of diss.... for D.Sc. (Econ):08.00.03/Dniprovskyi state agro-econ.university.Dnipro,36.

Mishenin, Ye.V. (1998). Ekologo-ekonomicheskie problemyi prirodopolzovaniya v lesnom komplekse (Ecological and economic problems of nature management in the forest complex): monograph / Ed. by Doctor of Economic Sciences, Prof. Koval Ya. V. Sumy: VTD «Mriya - 1» LTD, 272 (in Russian).

Malinovskaya, O. V., Skobeleva, I.P. (2014). Forsayt kak tehnologiya strategicheskogo planirovaniya i upravleniya (Foresight as a technology of strategic planning and management). Finansy ta kredyt - Finance and credit, 32(608),2 (in Russian).

Miles, I. (2004). Three Worlds of Foresight. EU-US Seminar: New Technology Foresight, Forecasting \& Assessment Methods.

Seville, 24-43. Retrieved from http://foresight.jrc.ec.europa.eu/fta/papers/Keynotes/Three Worlds of Foresight.pdf

Yarova, I.Ye. (2018). Forsaitna metodolohiia v systemi transformatsii prostorovoho rozvytku lisovoho kompleksu Ukrainy (Foresight methodology in the system of transformation of spatial development of forestry complex in Ukraine). Balanced natural resources: traditions, perspectives and innovations: Proceedings of the II International scientific-practical conference (Kyiv, December 21, 2018). Kyiv: DIA, $97-99$ (in Ukrainian).

Moiseev, N.A. (2010). Lesnaya ekonomika: problemyi i resheniya (Forestry: Problems and Solutions). Lesnoe hozyaystvo Forestry, 2, 34-38 (in Russian).

Antonenko, I.Ya. (2008). Ekoloho-ekonomichni priorytety modernizatsii lisoresursnoho kompleksu Ukrainy: makroekonomichn vazheli (Ecological and economic priorities of modernization of the forest resource complex of Ukraine: macroeconomic levers) / Ed. by Doctor of Economic Sciences, Prof. B.M. Danylyshyn. Kyiv: KUTEP - Inform, 359 (in Ukrainian).

Tretyak, V.P. (2015). Territorialnyie forsaytyi: opyit provedeniya, ozhidaniya i grazhdan i vlasti (Territorial foresight: experience of holding, expectations and citizens and power). Moscow: Znaniya, 215 (in Russian).

Sokolov, A.V. (2007). Vzglyad v buduschee (Looking into the future). Forsayt - Foresight, 1, 1-8 (in Russian).

Vasylkonova, E. (2014). Vykorystannia metodiv forsaitu u formuvanni pozytyvnoho imidzhu rehioniv (Using foresight methods in forming a positive image of regions). Proceedings of the ChSTU, 37(part II), 140-145 (in Ukrainian).

Haponenko, N.V. (2012). Foresight. Theory. Methodology. Experience. Moscow: Yunyty-Dana, 238 p. (in Russian).

The state of the world's forests 2009 / Food and agriculture organization of United Nations. Rome, 2009, 178 p.

Mishenin, Ye.V.Yarova,I.Ye. (2009) Ecological Economic Principles of Integrated Process Management for Forestry and Agriculture. Ecological economics and sustainable forest management: developing a transdisciplinary approach for the Carpathian Mountains:monograph. Lviv: Ukrainian National Forestry University Press, Liga-Pres, 432 p. (in English).

Khvesik, M.A, Bistryakov, I.K, Kapnova, D.V. (2016) Spatial organization and directions of use of natural wealth of Ukraine. Economy of Ukraine. №7 (48). pp.46-65 (in English).

Mishenin, Ye.V, Mishenina, H.A., Yarova, I.Ye. (2011). Conceptual and methodological bases of entrepreneurship development in forestry on the ecological and economic principles (Conceptual and methodological bases of entrepreneurship development in forestry on ecological and economic basis). Naukovyi visnyk NLTU Ukrainy - Scientific Bulletin of the National Forestry University of Ukraine, Issue 21.19, 182-196 (in Ukrainian).

Finansovo-ekonomichnyi mekhanizm upravlinnia terytorialnymy pryrodno-hospodarskymy kompleksamy (Financial and economic mechanism of management of territorial natural and economic complexes) / Ed. by Doctor of Economic Sciences, Prof. M.A. Khvesyk. Kyiv: DU IEPSR NAN Ukrainy, 2016. 528 (in Ukrainian). 
Y. Mishenin, I. Yarova, H. Mishenina. Features of Foresight Methodology Application in the Forestry Complex of Ukraine: Sectoral and Spatial Aspect

Є. В. Мішенін, д.е.н., профресор, Сумський державний університет (Україна);

I. Є. Ярова, к.е.н., доцент, Сумський державний університет (Україна);

Г. А. Мішеніна, к.е.н., доцент, Сумський державний університет (Україна).

Особливості застосування методології форсайту у лісовому комплексі Укарїни: галузево-просторовий аспект

У статті концептуально обгрунтовано сутнісно-змістовну основу застосування методології форсайту у лісовому комплексі у фрорматі сталого просторового лісогосподарювання. Соціоеколого-економічна результативність сталого лісогосподарювання визначається повнотою безперервного та невиснажливого користування усіма компонентами лісових екосистем, у тому числі неринковими, на всіх рівнях просторового розвитку (локальному, регіональному, національному та глобальному). Це обумовлює високу відповідальність світової спільности, суспільства, держави, територіальних громад та бізнесу за політичні, інституціональні, економічні, технологічні, проектні рішення у сфрері лісогосподарювання у просторово-часовому вимірі. Це спонукає до необхідності якісного прогнозування майбутнього сталого розвитку лісового комплексу, що обумовлює пошук і застосування сучасних есрективних підходів до стратегічного планування управління лісовим комплексом, серед яких особливо виділяється в останній час форсайт. Так, у роботі розглянуті ключові характерні особливості форсайту, які необхідно приймати до уваги при дослідженні майбутнього бачення сталого просторового розвитку лісового господарства. Таким чином, метою даної роботи є узагальнення та визначення особливостей $і$ можливостей застосування методології форсайту у лісовому комплексі у контексті сталого просторового розвитку лісогосподарювання. Зроблено акцент на необхідності урахування саме галузевих особливостей природокористування у лісовому комплексі у процесі форсайтних досліджень. Існуючі принципи та класифрікаційні ознаки форсайту представлено у контексті сталого лісокористування та управління лісами. Застосування існуючих методів форсайту реалізовано на прикладі використання сценарного підходу до обгрунтування організаційно-економічних умов формування та розвитку екосистемного підприємництва. При цьому застосування сценарного підходу нами розглянуто в межах вирішення проблеми розвитку лісогосподарського екосистемного підприємництва. Розвиток підприємництва на еколого-економічних засадах повинен стати якісно новим та ефективним типом ведення лісового господарства на основі застосування прогресивних, інноваційних способів, форм, методів організації виробництва та комбінації ресурсів. Представлена варіантна розробка використання сценарного підходу до обірунтування організаційно-економічних умов формування та розвитку лісогосподарського екосистемного підприємництва. Таким чином, застосування різноманітних форсайт-технологій (зокрема, сценарного підходу) буде забезпечуватиме якісно новий рівень конструктивного та багатоаспектного обґрунтування, зокрема, національної стратегії сталого розвитку лісового господарства, довгострокових програм лісовирощування на інноваційній основі.

Ключові слова: форсайт, лісовий комплекс, стале просторове лісогосподарювання, принципи форсайту, класифікація форсайту, сценарій, екосистемне підприємництво.

Manuscript received: 19.06.2019.

(c) The author(s) 2019. This article is published with open access at Sumy State University. 